\title{
リアルタイム NIRS バイオフィードバックシステムの园発 \\ Development of the Real-time Biofeedback System using NIRS
}

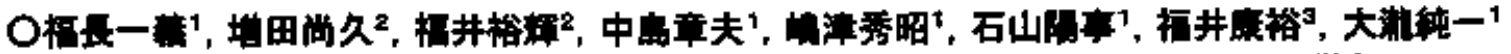

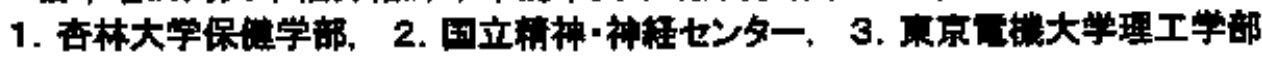

OKazuyoshi Fukunaga', Naohisa Masuda', Hiroki Fukui', Akio Nakajima', Hideaki Shimazu',

Yoji Ishiyama', Yasuhiro Fukui', and Junichi Otakj'

1. Faculty of Hoalth Sciences, Kyorin University,

2. National Center of Neurology and Psychiatry,

2. School of Science and Engineering. Tokyo Denki University

\section{HயUb|E}

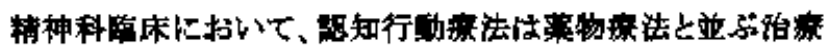

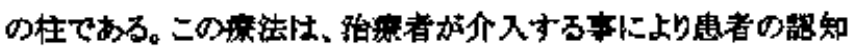

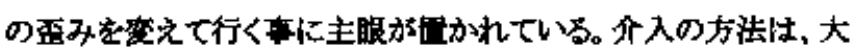

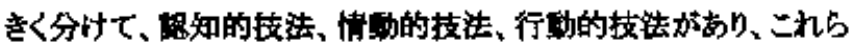

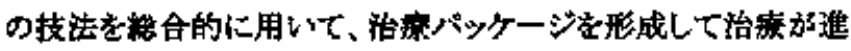
められていく。

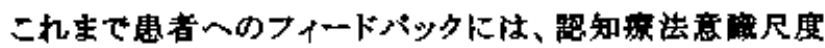

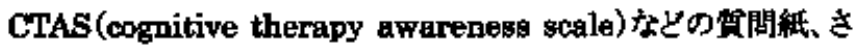

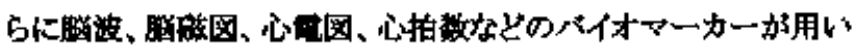
られてきたか、ての㿰果汇ついて未だ明らかになっていない。

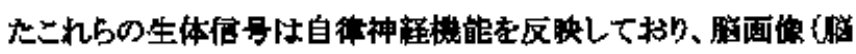
機釷そのものを计制しているかけではない。

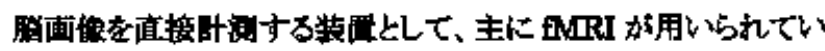
ろ。これまでに、ARI 索用いだイイオフィードバタクによって、患

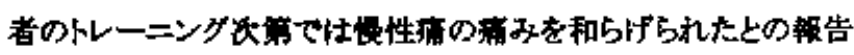
がある。 轨 AMRI ハイオフィードバッグ学習することによって、 自分の愿活助を索化させられたとの却告もある。

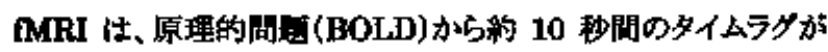
生しるため、真にりアルタイムハイオフィードバックを行らことは困

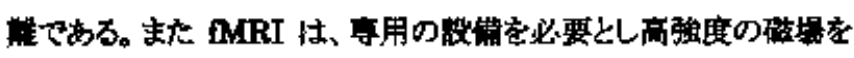

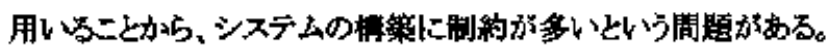

こ扎に対して近赤外線スベタトロスコピー (near infrared

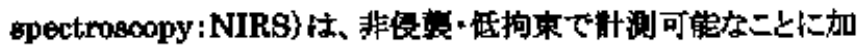

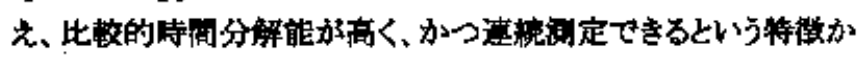

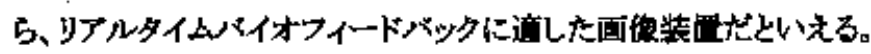

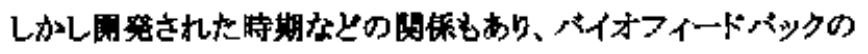

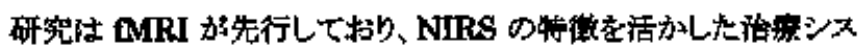
テムの研究は、知る限り行われていない。

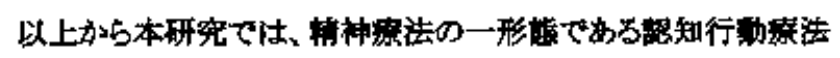

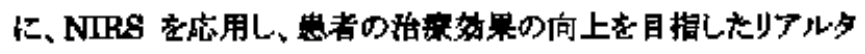
イムハイイオイードバックシステムを䁳することを目的とする。

\section{2. システムの标要}

本研究では NIRS 霍として、光トボグラフィーETG-4000（日立

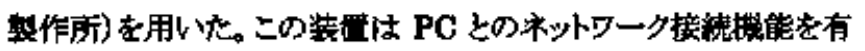

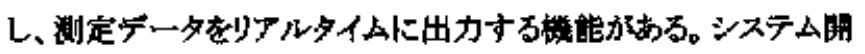

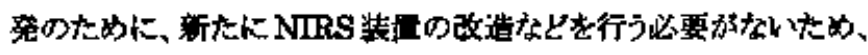
㜔床応用へのハードルを下げることが可能である。

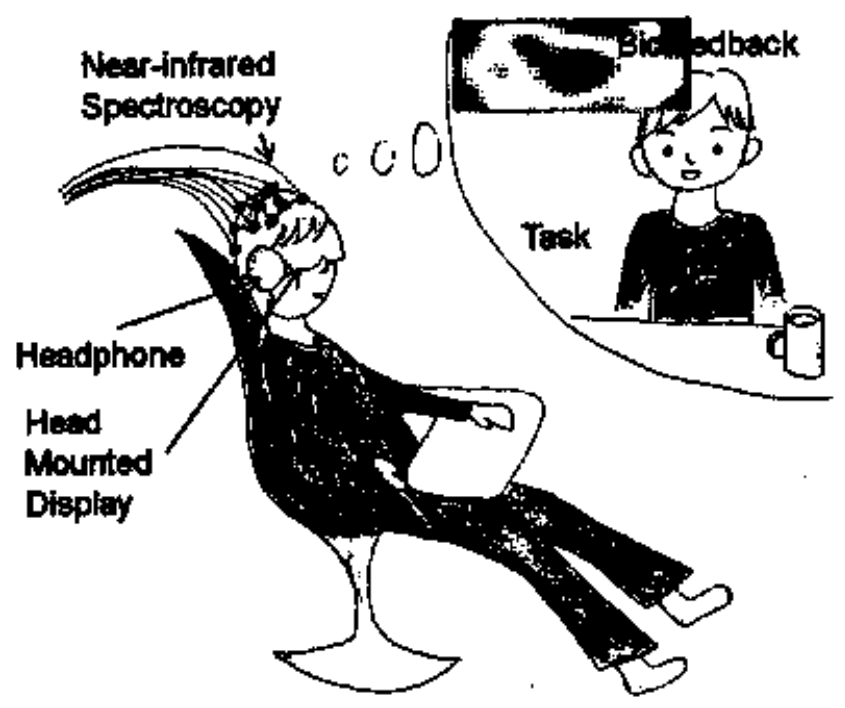

Fig.1 Outline of real-time biofoedback system

現在この機借安活かし、PC で取得したへモグロビン゙データ を高速て处理し、画像や音声标とのフィードバック信号学作 成し、被敛者に対してリナルタイムにバイオフィードバック を行うシステムの開笔を遭めている。

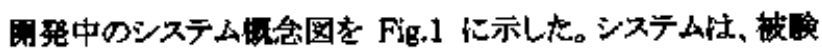
者に画㒀を缰示するヘッドマウントディスプレイ(i-visor DH-4400VP·Personal Displey Systems, Inc.)、党提示老行う人

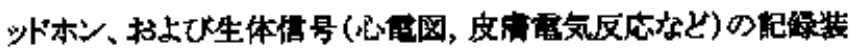
加棈成した。

\section{3. $4: 2017$}

例えば画僚に上るパイオフィードバックを行うためには、NIRSの

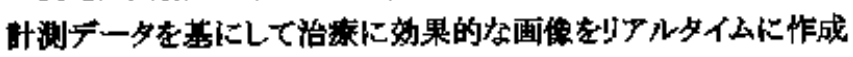
し、ピテオ出力オる必要がある。提示田化として、手始めに 2 次

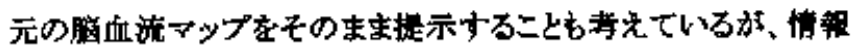
が多すぎて柀园者が面信在上手に活用できず、想定した結果が 得らえない可能性加ある。そこて、例えはナロダメータのような

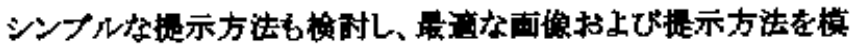
索していく予定である。また，音声その他のフィードイ゙ックについ ても检邻してい。 